\title{
Monetary Policy and Return on Equity of Quoted Insurance Firms: A Time Series Study from Nigeria
}

\author{
Macfubara, Minafuro Suzane ${ }^{1}$, Norteh Dumbor ${ }^{1} \&$ Gberesuu, Barida Barry ${ }^{1}$ \\ ${ }^{1}$ Insurance and Risk Management Department, Ken Poly, Bori, Rivers State ,Nigeria \\ Correspondence: Macfubara, Minafuro Suzane, Insurance and Risk Management Department, Ken Poly, Bori, \\ Rivers State, Nigeria
}

Received: May 5, 2018

Accepted: May 26, 2018

Online Published: June 6, 2018

\begin{abstract}
The financial system is the transmission channel of monetary policy. This study examines the effect of monetary policy on the performance of insurance firms in Nigeria from 1990 - 2017. The objective is to investigate the existing relationship between monetary policy instruments and the performance indicators of insurance companies. Secondary data were sourced from Stock Exchange factbook, Central Bank of Nigeria (CBN) Statistical Bulletin. Multiple linear regressions were formulated to examine the effect of the independent variables on the dependent variable. Return on equity was modeled as a function of treasury bill rate, monetary policy rate, interest rate, growth of money supply and exchange rate. $\mathrm{R}^{2,}$ T-Statistics, $\beta$ Coefficient, F-Statistics and Durbin Watson were used to examine the extent to which the independent variables affect the dependent variables while augmented dickey fuller unit root test, granger causality test, cointgration test and error correction models was used to ascertain the dynamic relationship between monetary policy variables and return on equity of the insurance firms. Findings revealed that, all the explanatory variables have positive effect on return on equity except treasury bill rate. The unit root test found that the variables are stationary at first difference, the cointgration test found the presence of long run relationship while the granger causality test found a uni-directional causality. The study concludes that monetary policy has moderate effect on the return on equity of the insurance firms. We recommend that management of insurance companies should devise measures of managing the negative effects of the monetary policy instruments to enhance the performance of the insurance companies.
\end{abstract}

Keywords: Monetary Policy, Return on Equity, Quoted Insurance Firms, Monetary Policy Rate, Treasury Bill Rate.

\section{Introduction}

Monetary policy has long been acknowledged as instrument used to influence investment and other macroeconomic indicators. The opinion that the non-banks financial institutions matters in the transmission of monetary policy can be traced to the Radcliffe committee meeting of 1950s which suggested strongly that the non- bank financial institutions such as insurance companies can influenced and be influenced by monetary policy and thereby be brought under the control of monetary authorities. This led to the redefinition of money supply as Ms $=\mathrm{C}+\mathrm{DD}+$ SD + TD + NBFI (Onoh, 2002).

Insurance companies provide unique financial services to the growth and development of every economy. Such specialized services ranges from underwriting of risk and mobilization of long-term fund for capital investment, hence monetary policy variables can affect the performance of the industry negatively or positively. The relationship between monetary policy and performance of private investment and financial institutions is perennial issue in development economic judging from the hundreds of theoretical and empirical scholarly papers that have been written to capitalize how monetary variables such as interest rate, money supply, monetary policy rates and liquidity reserves, money supply, affect private investment or financial institutions. Morgan (1981) identified two casual relationships between monetary policy instruments and return on private investment which are finance-led hypothesis and growth led hypothesis.

The effect of monetary policy variables such as interest rate, money supply, monetary policy rate and liquidity on the qualitative measures of insurance of insurance performance such as profit, investment, employment and cash flow is lacking in Literature. However, it is generally accepted in theory and principle that the financial sector which 
includes the insurance industry is the transmission mechanism for the realization of government monetary and macroeconomic goals.

Despite the growing literature on the relationship between monetary policy and the performance of the financial institutions, the effect of monetary policy on the Non-banks financial institutions such as the insurance companies is lacking in literature as significant proportion of literature is focused on the effect of money banks. This creates a knowledge gap in the effect of monetary policy on the performance of insurance companies in Nigeria. Again, the existing literatures and findings on the effect of monetary policy and the performance of financial institution is inconclusive and controversial as some report positive while others report negative effect. This result to failures or report negative effect, this result to failures of monetary authorities in effect management of monetary policy to achieve prudential and financial sector stability. The failure of previous financial policies of government to achieve desirable economic growth was the concern that demands re-structuring of the system, especially in the era of an ailing economy (Dagogo and Okorie, 2014). This results to the difficulties of accessing the relative effect of monetary policy on the non-bank financial institutions. From the above, this study intends to examine the effect of monetary policy on the performance of insurance companies in Nigeria. The following null hypotheses are formulated from the variables:

- There is no significant relationship between Treasury bill rate and return on equity of quoted insurance firms in Nigeria.

- There is no significant relationship between monetary policy rate and return on equity of quoted insurance firms in Nigeria.

- There is no significant relationship between interest rate and return on equity of quoted insurance firms in Nigeria.

- There is no significant relationship between growth of money supply and return on equity of quoted insurance firms in Nigeria.

- There is no significant relationship between exchange rate and return on equity of quoted insurance firms in Nigeria.

2. Literature Review

2.1 Insurance in Nigeria

Insurance companies provide unique financial services to the growth and development of every economy. Such specialized service ranges from the underwriting of risks inherent in economic entities and the mobilization of large amount of funds through premium for long-term investment (Akotey et al, 2011). The risk absorption role of insurers promotes financial stability in the financial entities (Lowes, 2010). Categorically, insurance in Nigeria is classified into life, general, composite and reinsurance (Ezirim, 2003). Apart from the risk management functions, insurance policy such as life and whole life is an aspect that provide savings plans and in direct completion with the investment in other financial institutions such as the deposit money banks, savings associations, mutual funds and real estates and other real and financial investments (Ezirim and Muoghalu, 2002). Insurance plays financial intermediation function, a major source of long-term capital and facilitate the growth of the capital market (Catalan et al., 2000). Hence monetary and macroeconomic shocks can affect positively or negatively insurance investment. Nigerian government over the years has embarked on monetary and macroeconomic reforms to enhance real and portfolio investment in the financial sector. For instance the deregulation of interest rate and the financial sector in the last quarter of 1986, the reforms in the foreign exchange market to attract foreign real and portfolio investment, the establishment of National Insurance Commission (NAICON) in 1997. The enactment of the insurance Act 2003 which increase the capital base of the categorized insurance businesses to $\$ 15 \mathrm{~m}$ for life insurance, $\$ 200 \mathrm{~m}$ for general insurance and $\$ 350 \mathrm{~m}$ for reinsurance and the recapitalization policy in 2005 which further increase the capital base to $\$ 2$ billion life insurance, $\$ 3$ billion non life and $\$ 1$ billion reinsurance which reduce number of insurance companies from 104 to 49, reinsurance from 4 to 2 (Fatula, 2007) with the objective of consolidating in the sector maximize investment returns and to attract foreign capital infusion (Ayeleso, 2010). However, the extents to which these reforms have affected investment in the insurance industry remain a matter of research interest as investment in the industry continues to decline. Record revealed that only $10 \%$ of Nigerian have insurance policy of any type (Mordi, 1990, Wilson, 2004). A close examination of CBN Report (2012) indicate that total investment of Nigerian insurance industry total $\$ 336,247.9$ in 2008 , $\$ 343,894.2$ in $2009, \$ 351,459.9$ in 2010 and $\$ 359,192.0$ in 2011 representing a marginal annual increase of $2.89 \%$ compared with the commercial banks of $43.78 \%$.

2.2 Conceptual of Monetary Policy

Monetary policy is defined by the Central Bank of Nigeria (CBN) as combination of measures designed to regulate value supply and cost of money in an economy, in consonance with the level of economic activities. Odufalu, (1994) defined monetary policy as the combination of measures taken by monetary authorities (the CBN and the ministry of 
finance) to influence directly or indirectly both the supply of money and credit to the economy and the structure of interest rate for economic growth, price stability and balance of payment equilibrium. He added that the CBN is empowered by decree 25 of 1991 Act, to formulate and implement monetary policy in Nigeria, in consultation with the ministry of finance subject to the approval of the President. Onyido (1993) sums it up when he said that monetary policy is therefore applied to influence the availability and cost of credit in order to control the money supply policy. He generally describe the action taking by the Central Bank as using tools / instrument at its disposal to influence monetary conditions in particular, the quantity and supply of money in the macro-economic goals.

2.3 Agency Theory

Most of the hypotheses formulated in the following are based on the economic principal-agent theory, where a positive effect stems from the amelioration of the shareholder-management conflict, by disciplining the management. Analogously, an aggravation of the conflict results in a negative effect. The principal-agent theory is part of the new institutional economics, which developed as extension of the neoclassicism. It abandons the assumption of a complete market by allowing informational asymmetries and transaction costs to cause incomplete contracts. This leads to a methodological individualism, which does no longer consider institutions as profit maximizing collectives, but as a "nexus for a complex set of explicit and implicit contracts of individuals. Consequently, the economic focus on markets is shifted to man-made institutions, incorporating the individual into economic theory.

\subsection{Empirical Review}

Mazviona, Dube and Sakahuhwa (2017) examined factors affecting the performance of insurance companies in Zimbabwe. We utilized secondary data from twenty short-term insurance companies. The data was for the period from 2010 to 2014. We used factor analysis and multiple linear regression models to determine the factors affecting performance and identifying their impact. The findings revealed that expense ratio, claims ratio and the size of a company significantly affect insurance companies' performance negatively, whilst leverage and liquidity affect performance positively. Gonga and Sasaka (2017) investigated the determinants of financial performance of selected insurance firms in Nairobi County. The target population was 55 licensed insurance firms (42 locally owned insurance firms and 13 Foreign owned insurance firms). The study used two respondents in each insurance firm who were Finance Managers and Corporate Affairs Managers and all these had total of 96 respondents. The study used both primary and secondary data. The main primary data source was semi structured questionnaire. The data from the study was analyzed qualitatively and quantitatively using percentages, means and frequency distribution with the aid of Statistical Package for Social Sciences (SPSS) version17. Since data was descriptive, variants such as means, frequencies and percentages were used to describe the findings of the study. Bivariate ANOVA statistical data analytical technique was used to find the determinants of financial performance of selected insurance firms in Nairobi County. The study concluded that insurance firms had liquid investments which helped them to settle claims especially if their underwriting income cannot cover claims. The firms would sell off their investments if they lacked money to settle claims. Majority of insurance firms relied on cash flow from operations in liquidity management. This implied that all firms had certain source of funds for liquidity management. The study recommended that insurance firms should establish a well matched portfolio of their assets and liability in terms of cash flows or rather they should ensure that they create additional reserve so that it can assist them to cover the interest rate since low interest may create a discrepancy on the earnings.

Yuvaraj and Abate (2013) examined on factors affecting profitability of insurance companies for nine years (20032011) in Ethiopia using 7 firm specific factor (i.e. age of company, size of company, volume of capital, leverage ratio, liquidity ratio, growth and tangibility of assets) on profitability. According to their regression results they found that size is most important factor and positively related with profitability. Daniel and Tilahun (2013) also studied on Firm specific factors that determine insurance companies' performance in Ethiopia using 7 firm specific factors (i.e. size, leverage, tangibility, Loss ratio (risk), growth in writing premium, liquidity and age) on 9 insurance companies for six consecutive year staring from 2005-2010 and they found that insurers' size is statistically significant and positively related with return on total asset.

Abate (2012) studied factors affecting insurers profitability in Ethiopia sampling nine of insurance companies for nine years (2003-2011) and found out that assize is the most important determinant factors of profitability and positively related with it. Mistere (2015) also found out the same result. The effect of size on profitability in this study also was found to be significant and positively related with profitability. Nino (2016) examined the association between Insurer-specific indicators and macroeconomics on profitability in Philippine non-life insurance market utilizing the panel data over the period of 2008 through 2012. Return on assets (ROA) and operating ratio were used for profitability. The study found out that that firm size significantly affects profitability both in ROA and operating ratio. 
Hamdan (2008) examined determinants of insurance company's profitability in UAE, the study revealed that there is significantly positive relationship between profitability and size. Bilal Javaria et al. (2013) similarly, investigated on the determinants of profitability in insurance sector of Pakistan with a panel data set of 31 insurance firms, and they found that size, earnings volatility and age of the firm are significant determinants of profitability. Bilal Javaria $e t$ al. (2013) investigated on the determinants of profitability in insurance sector of Pakistan with a panel data set of 31 insurance firms (life insurance sector and no-life Insurance) of Pakistan from 2006-2011 the study suggests an opposite and significant relationship between leverage ratio as independent variables and profitability. Shami and Ahmed (2008) explore on determinants of Insurance Companies' Profitability in UAE using 5 firm specific variables and they found that an opposite and significant relationship between leverage ratio as independent variables and profitability. Hen-Ying Lee (2014) also estimated the effects of firm specific factors and macroeconomic factors on profitability (measured by operating ratio and ROA) of property liability insurance industry in Taiwan and he found that financial leverage is significantly and negatively correlated with profitability.

AnilaÇekrezi (2015) investigated factors that affect financial performance of Albanian Insurance Companies the study population consisted of 5 insurance companies with private capital, for the period 2008-2013 with a total of 30 data. The results showed that leverage has negative impact on the financial performance (ROA) of these companies. Therefore, in this study too it was found out that leverage has a significant effect and statistically negative relationship with profitability. Curak et al. (2012) examined the determinants of the profitability of the Croatian composite insurers' between 2004 and 2009. The determinants of profitability, selected as explanatory variables include both internal factors specific to insurance companies and external factors specific to the economic environment. By applying panel data technique, the authors show that underwriting risk (loss ratio) had a significant influence on insurers' profitability.

Umotho (2013) examined the relationship between firm specific and macroeconomic variables with financial performance of insurance companies. In his study he investigated the relationship of interest rate; inflation rate (CPI), currency exchange rate fluctuations, money supply, GDP, as macro-economic factor, and Claim ratio (CR) and he found that Claim ratio has positive effect on ROA. Therefore, this study is also consistent with most of the previous studies and found out that loss ratio is negatively related with profitability and its effect is significant. Chen-Ying Lee (2014) also estimated the effects of firm specific factors and macroeconomic factors on profitability (measured by operating ratio and ROA) of property-liability insurance industry in Taiwan and he found that reinsurance is significantly and positively correlated with operating ratio. However, in case of profitability measured by ROA, he found that underwriting reinsurance is positively correlated with ROA. Ornella and Anderloni (2014) tested the impact of several firm characteristics, such as dimension, capital structure and investment policies on economic performance for a panel of non-life insurance firms operating in the main European markets spanning from 2004 to 2012.The findings suggest that various factors contribute to the performance measured by return on equity and return on asset. According to the study, the three main areas that constitute the core insurance activity (insurance in its narrower sense, financial and reinsurance activities) strongly influence profitability, but reinsurance does not seem to contribute either positively or negatively to performance.

Muhaizam Ismail (2013) investigates the determinants of financial performance of general Islamic and conventional insurance companies in Malaysia using panel data over the period of 2004 to 2007, using investment yield as the performance measure. This measure is related to a number of economic and firm specific variables, which are the profit/interest rate levels, equity returns, size of company, retakaful/reinsurance dependence, solvency margin, liquidity, and contribution/premium growth, chosen based on relevant theory and literature. Based on the empirical results, the study found that retakaful dependence is statistically significant determinants of the investment performance of the general Islamic insurance companies in Malaysia.

Kozak (2011) examined determinants of profitability of non-life insurance companies in Poland during integration with the European financial system for the period of 2002-2009 and suggested that Companies improve profitability and cost efficiency with an increase of their gross premiums and decrease of total operating expenses. Additionally increases of the GDP growth and the market share of foreign owned companies positively impact profitability of nonlife insurance companies during the integration period. Cassandra et al (2015) in their multivariate analysis, they find evidence that market concentration and insurers' underwriting profits are positively related. More specifically, insurers in states with greater market concentration are more profitable than insurers in states with lower levels of market concentration

Öner Kaya (2015) investigated the determinants of profitability in the Bosnia and Herzegovina insurance industry between the years of 2005- 2010. According to their results, age of company, market share, and past performance are positively and significantly related with current profitability they have also found that foreign owned companies perform better than domestically owned companies; and there is no significant relationship between diversification 
and profitability. In this study also, it was found that market share correlates positively wit profitability and had insignificant effect, which is consistent to the above studies. Michael Doumpos et al (2012) Using a sample of over 2000 nonlife insurance firms operating in 91 countries between 2005 and 2009, they found that macroeconomic indicators such as real GDP growth, inflation, and income inequality influence the overall performance of firms and a statistically significant effect on the overall performance of insurers.

Kozak (2011) examined determinants of profitability of non-life insurance companies in Poland and according to the study of the GDP growth and the market share of foreign owned companies positively impact profitability of nonlife insurance companies. Suheyli Reshid (2015) found that economic growth rate has significant influence on profitability. Mister (2015) found that economic growth is not significant determinants of profitability. Hadush (2015) found that GDP is negatively but significantly related with profitability. GDP growth shows positive but insignificant relationship with insurers' profitability. Hana Mariam (2015) found that out that GDP growth shows positive but insignificant relationship with insurers' profitability. Nino Datu (2016) examined the association between Insurer-specific indicators and macroeconomics on profitability in Philippine non-life insurance market utilizing the panel data over the period of 2008 through 2012. Return on assets (ROA) and operating ratio were used for profitability. According to the study there was no evidence found in the Gross Domestic Product (GDP) on profitability in both ROA and operating ratio. In this study, GDP was found to be negatively related with profitability and it has insignificant effect on profitability. Therefore the studies were found to be contradictory.

Chen-Ying Lee (2014) found that inflation rates exhibit negative correlation with ROA, but is not significantly different from zero. Curak et al. (2012) examined the determinants of the profitability of the Croatian composite insurers' between 2004 and 2009. The finding showed that inflation and return on equity have a significant influence on insurers' profitability. Michael Doumpos et al (2012) Using a sample of over 2000 nonlife insurance firms operating in 91 countries between 2005 and 2009,they found that macroeconomic inflation influence the overall performance of firms and a statistically significant effect on the overall performance of insurers. ViktoriaNikolaus (2015) examines determinants of firm performance of Indonesian and Dutch firms over the period of 2009-2013. The study found that Inflation, which is high in Indonesia, has a negative influence. The more moderate inflation rate of the Netherlands leads to a positive, although not significant effect.

Nino Datu (2016) examined the association between Insurer-specific indicators and macroeconomics on profitability in Philippine non-life insurance market utilizing the panel data over the period of 2008 through 2012. Return on assets (ROA) and operating ratio were used for profitability. According to the study there was no evidence found that inflation has effect on profitability in both ROA and operating ratio. In this study, inflation has negative relationship with profitability and it affects profitability insignificantly. Chukwulozie (2006) explained that low level of income, low level of education, lack of insurance awareness, high inflation rate, lack of reliable Actuarial data for research and underdeveloped financial market had affected savings for life insurance consumption. Although, his work was based on life insurance as a source of long term savings, there is no empirical evidence to justify his work. Zhu (2007) explained that life insurance and stock purchases are independent of each other; life insurance purchases influence by individual's income, bequest intensity, risk attitude, survival probability, and the insurance risk premium and stock purchases are affected by individuals' income, risk attitude, the risk free rate of return, stock return, stock volatility. Life insurance and stock purchases are positively related with each other and affected by all factors. Chui and Kwok (2008) examined that national culture affects the consumption pattern of life insurance across countries. Research hypothesis were tested empirically by using Hofstede's cultural dimensions and data from 1976-2001 across 41 countries and found that individualism indeed has a significant, positive on the life insurance consumption, whereas power distance and masculinity/ femininity have significant, negative effects. Chen and Mau (2009) focused on ethical and non-ethical sales behavior of salesperson's regarding customer trust in the salespersons' and in the company which affects customer loyalty in the life insurance industry and found that the salesperson's ethical sales behavior does play a crucial role in customer loyalty through customer trust.

Malik (2011) investigated that determinant of profitability in insurance industry in Pakistan, the effect of factors such as age of company, size of company, volume of capital, loss ratio and leverage ratio on profitability. The sample of 35 life and non-life insurance cover the period of 2005-2009 and concluded that there is positive association between size of company and profitability and there is no relationship between profitability and age of company and also showed that volume of capital is significantly and positively related to profitability. Leverage ratio and loss ratio showed negative but significant relationship with profitability.

Tang (2001) revealed that some sources of customer value such as relational quality price and corporate image were differentiated significantly across psychographic segments while service and product qualities were not significantly affected by psychographics, service quality was found to be the core factors to all customers. By applying factor analysis and K-means clustering methods were used to develop psychographic segments and concluded that 
demographic and psychographic characteristics found to have significant effect on sources from which customers derived value. Ayaliew (2013) examine the determinants of life insurance for a time series data for the period 19912000. There is a casual relationship between life insurance sector development and economic growth in the developing country. This study showed that life insurance is determined by per capita income, life expectancy, real interest rate and inflation.

Oke et al (2010) examined the determinants of life insurance consumption in Nigeria during the period 1970-2005 within an error correction framework. Co-integration technique revealed that real gross domestic product and structural adjustment facility positively and significantly influence life insurance consumption in Nigeria while indigenization policy and domestic interest rate are statistically significant but inversely related to life insurance consumption. On the other hand return on investment, inflation rate, openness of the economy, political instability are insignificant predictors of life insurance consumption in Nigeria. Moullee et al., (2013) showed that insurance consumption decision is influenced by monetary considerations such as consumer's evaluation of a service in monetary terms and the search for the possibility to reduce the amount premiums payable for insurance and indicated that demographical and socio-economical characteristics of consumers influence their behavior. Factor analysis and multiple regression analysis were used to determine how the factors are formed and their relative's weights. Five factors had been identified the acceptability of insurance condition, insurance service providers competence, consumers monetary attitudes towards insurance, the positively of consumers insurance experience, and the possibility to reduce the amount of premiums payable for insurance.

Lee (2001) found that without aging process, the purchase rate in 1990 and 1995 was lover. The baby boomers purchase less life insurance than their earlier counterparts and this phenomenon consequently led to the decline of recent life insurance purchases in the U.S. Men show a strong age effect and strong negative cohort effects while women have strong positive cohort effects. Wee et al (2007) examined the determinants of life insurance consumption in OCED countries and found that there is significant positive income elasticity of life insurance demand. Demand increases with the no of dependents and level of education and decrease with the expectancy and social security expenditure whereas high inflation and real interest rates tend to decrease consumption. Life insurance demand was better explained when the product market and socioeconomic factors were jointly considered. Omar and Frimpong (2007) found that increased level of consumer consciousness and lack of welfare benefits were increasing growth factors for the life insurance market in Nigeria and the purchase behavior towards life insurance was determined by normative factors, the suggestion was that the initial point of contact for marketing communication regarding the purchase of life insurance should have family and friends.

Beck and Webb (2002) highlighted the issues of finding the reasons behind the variations in life insurance consumption by using unbalanced panel data of 68 countries from 1961 to 2000 . They employed four various proxies of consumption, economic, demographic and institutional factors. Results cleared that countries with large income per capita, stable banking sector and lower inflation tend to use huge quantity of life insurance. In addition to its life insurance consumption was observed to be directly affected by private savings and real interest rate. Demographic elements such as education, urbanization, life expectancy, young and old dependency ratio had not any robust effect on the life insurance consumption. Hwang and Gao (2003), examined the elements for life insurance demand in China by explaining the huge growth in this industry after the economic reforms of 1978. Study found that the basic element that have effected people to buy insurance policies are positively related to upper stages of economic security, the rise in the education level and the modification in social structure. However, this study had not found an inverse influence of inflation on life insurance consumption; even China faced large inflation in the mid-1990s.

Sen and Madheswaran (2007) investigated the role of economic and political variables in the life insurance consumption pattern of 4 SAARC, 6 Asian and 2 greater China region economies from 1994 to 2004. Insurance penetration and density were the dependents element in cross country analysis and the estimates of fixed and random effects model proved that incomes, savings and inflation were main variables in describing insurance consumption. Study also done the time series analysis of life insurance demand for India from 1965 to 2004 and findings cleared that income (GDP per capita), financial depth, per policy price of insurance products and real interest rates were significant factors. Nesterova (2008) explored the modifications in life insurance demand for 14 countries of former Soviet Union and Central and Eastern Europe including Ukraine from 1996-2006. Panel results cleared that economies with greater life expectancy at birth, income and education level, old dependency ratio had larger life insurance consumption while, financial development, inflation and real interest rate decreased the life insurance demand across countries, whereas, young dependency ratio, urbanization level and institutional factors did not had any significant relation to life insurance demand. 
Ade et al, (2010) explored the elements of life insurance consumption in Nigeria by using Co integration and Error Correction Model from 1970-2005. Study found the presence of a long run link and a short run dynamics among the factors. Co-integration results cleared that real gross domestic product and SAP directly and significantly affect Life Insurance demand in Nigeria while indigenization policy and interest rate are statistically significant but negatively linked to life insurance demand. On the other side study found that return on investment, inflation, openness and political instability are insignificant determinants of life insurance demand.

Chen and Wong (2004) revealed that size, investment and liquidity are significant determinants of the profitability of insurers. However, Ahmed et al., (2011) in a similar study of the Pakistani life insurance industry, claimed that liquidity is not a significant determinant of insurers' profitability. They posited that, whereas size and risk (loss ratio) are significant and positively related to the profitability of insurance firms, leverage is negative and hence decreases the profitability of insurers significantly.

Malik (2011) delved into the determinants of the financial performance of 35 listed life and non-life companies covering the period of 2005 to 2009. Although his study covers both sectors of the insurance business, much of his findings seem to confirm that of Ahmed et al (2011). Specifically, Malik found that whereas size and capital have strong positive association with insurers' profitability, loss ratio and leverage have strong inverse relationship with profitability. Hrechaniuk et al. (2007) examined the financial performance of insurance companies in Spain, Lithuania and Ukraine. Their results showed a strong correlation between insurers' financial performance and the growth of the written insurance premiums. Pervan and Pavic (2010) and Curak et al (2011) investigated into the impacts of firm-specific, industry-specific and macroeconomic variables on the financial performance of the Croatian non-life and composite insurance companies respectively. The results of Pervan and Pavic revealed an inverse and significant influence of ownership, expense ratio and inflation on profitability. In lending support to the findings of Pervan and Pevic (2010), Curak et al (2011) indicated that size, underwriting risk, inflation and equity returns have significant association with composite insurers' financial performance.

There has not been any known study on the effect of monetary policy on the performance of the insurance industry in Nigeria. Similar study such as Aburieme (2008) examined the effect of monetary policy on the performance of Nigerian banking industry. The neglect in empirical research can be traced to the indirect effect of monetary policy on the insurance industry.

3. Research Methodology

Data collections for this study were from secondary sources of information. The sources include the Central Bank of Nigeria (CBN), financial statement of the quoted insurance firms, textbooks, and journals, write ups and various publications such as CBN statistical bulletin and periodical Bulletin. A regression method of Ordinary Least Square (OLS), granger causality test, error correction estimate, Augmented Dickey Fuller unit root test and Johansen co-integration test of research design were adopted to ascertain the effect of monetary policy on return on equity of the quoted insurance firms within the periods covered in this study.

3.1 Analytical Framework

The econometric model to consider in this study takes monetary policy and return as the explanatory variables and return on equity as dependent variable respectively. These variables are used at constant prices to obtain a reliable parameter estimates in the time series regression. This study used the multiple regression models. The test is basically modeled based on an estimated regression model, by Ordinary Least Square (OLS) estimator (Pesaranet al., 2001). An F-test of the joint significance of the coefficients of the model, the variables was used to test the hypothesis of no co-integration among the variables against the presence of co- integration among the variables. The null hypothesis of no co-integration between the dependent and the independent variables as specified below:

$\mathrm{ROE}=\mathrm{f}(\mathrm{EXR}, \mathrm{INTR}, \mathrm{TBR}, \mathrm{MPR}, \mathrm{G}-\mathrm{M} 2)$

It is empirically stated as

\begin{tabular}{|c|c|}
\hline Where & \\
\hline ROE & Return on Equity of the Quoted Insurance Firms \\
\hline EXR & Naira Exchange Rate per US Dollar \\
\hline INTR & Interest Rate \\
\hline TBR & Treasury Bill Rate \\
\hline MPR & Monetary Policy Rate \\
\hline G-M2 & Growth of Money Supply \\
\hline
\end{tabular}


Formulating model for hypotheses testing

Hypothesis I

$\begin{array}{llll}\mathrm{ROE} & =\beta_{0}+\beta_{2} E X R+\mu & 3 \\ \mathrm{ROE} & =\beta_{0}+\beta_{2} I N T R+\mu & 4 \\ \mathrm{ROE} & =\beta_{0}+\beta_{2} T B R+\mu & 5 \\ \mathrm{ROE} & =\beta_{0}+\beta_{2} M P R+\mu & 6 \\ \mathrm{ROA} & =\beta_{0}+\beta_{2} G-M 2+\mu & 7\end{array}$

3.2 Estimation Procedure

\subsubsection{Unit Root Test}

Most of time series have unit root as demonstrated by many studies including Nelson and Plosser (1982), Stock and Watson (1988) and Campbell and Peron (1991). Therefore, their means of variance of such time series are not independent of time. Conventional regression technique based on non-stationary time series produce spurious regression and statistic may simply indicate only correlated trends rather true relationship Granger and Newbold (1974). Spurious regression can be detected in regression model by low Durbin Watson and relatively moderate $\mathrm{R}^{2}$. Therefore, to distinguish between correlation that arises from share trend and one associated with an underlying causal relationship; we use both the Augmented Dickey fuller (Dickey and Fuller, 1979, 1981)

$X_{t}=\mu+\Theta X_{t-1}+\varepsilon_{t}$

The null hypotheses for the ADFstatistic test are $\mathrm{H}_{0}$.

Non stationary (unit root) and $\mathrm{H}_{0}$ : Stationary respectively

3.2.2 Cointegration

To search for possible long run relationship amongst the variables, we employ the Johansen and Juselius (1990) approach. Thus, the study constructed a p-dimensional $(4 \mathrm{x} 1)$ vector auto regression model with Gaussian errors that can be expressed by its first differenced error correction form as

$\Delta Y_{t}=\Gamma_{1} \Delta Y_{t-1}+\Gamma_{2} \Delta Y_{t-2}+\ldots . .+\Gamma_{k-1} \Delta Y_{t-k+1}-\Pi Y_{t-1}+\mu+\varepsilon_{t}$

Where $\mathrm{Y}_{\mathrm{t}}$ are the data series studied, $\varepsilon_{t}$ is i. i. $\mathrm{d}, \mathrm{N}(0, \Sigma) \Gamma_{i}+-1+\mathrm{A}_{1}+\mathrm{A}_{1}+\mathrm{A}_{2}+\mathrm{A}_{3}+\ldots \ldots+\mathrm{A}_{\mathrm{i}}$ for $\mathrm{i}=$ $1,2,3 \ldots \ldots, \mathrm{k}-1, \Pi=\mathrm{I}-\mathrm{A}_{1}-\mathrm{A}_{2}-\ldots \ldots-\mathrm{A}_{\mathrm{k}}$. The $\Pi$ matrix conveys information about the long term relationship among the $Y_{t}$ variables studied. Hence, testing the cointegration entails testing for the rank $r$ of matrix $\Pi$ by examine whether the eigenvalues of $\Pi$ are significantly different from zero. Johansen and Juselius (1990) proposed two tests statistics to determine the number of cointegrating vectors (or the rank of $\Pi$ ), namely the trace and the maximum eigen-value ( $\lambda$-trace) is computed as;

$\lambda$ trace $=-T \sum_{j=r+1}^{n} \operatorname{In}\left(1-\lambda_{j}\right)$

The trace tests the null hypothesis that "at most" $r$ cointegration vector, with "more than" $r$ vectors being the alternative hypothesis. The maximum eigenvalue test is given as:

$$
\lambda_{\max }=-\operatorname{TIn}\left(1-\lambda_{r+1}\right)
$$

It tests the null hypothesis of $r$ cointegrating vectors against the alternative hypothesis of $r+1$ cointegration vectors. In the equation (3) and (4), is the sample size and $\lambda$ is the largest canonical correlation.

3.2.3 Granger Causality

In case we do not find any evidence for cointegration among the variables, the specification of the Granger causality will be a vector auto regression (VAR) in the first difference form. However, if will find evidence of cointegration, there is the need to augment the Granger-type causality test model with a one period lagged error term. This is a crucial step because as noted by Engel and Granger (1987).

$$
Y_{t}=\alpha_{o}+\sum_{i=1}^{n} \alpha_{1}^{y} Y_{t-1} \sum_{i=1}^{n} X_{a 1} X \mu
$$

and

$$
X_{t}=\beta_{o}+\sum_{i=1}^{n}{ }_{\beta 1}^{y} Y_{t-1} \sum_{i=1}^{n} X_{\beta 1} X Y_{t}
$$




\subsubsection{Error Correction Model (ECM)}

Co-integration is a prerequisite for the error correction mechanism. Since co-integration has been established, it is pertinent to proceed to the error correction model.

4. Analysis and Discussion of Findings

To contribute on the existing body of knowledge on the effect of monetary policy on the performance of insurance companies in Nigeria, this study used data sourced from Central Bank of Nigeria Statistical Bulletin, comprising Growth rate of Money Supply, Interest rate, Monetary Policy rate, Exchange Rate and Treasury Bill Rate variable as independent variables while insurance performance is the dependent variables which is proxy by return on capital employed of the industry. The multiple regression models formulated in section three of this study was used to examine if there are any significant affect between monetary policy variables and the performance indicator of insurance companies.

Table 1: Presentation of Results

\begin{tabular}{crrrr}
\hline Variable & Coefficient & Std Errs. & T-Statistics & \multicolumn{1}{c}{ Prob. } \\
\hline TBR & -3.128729 & 4.405528 & -0.710182 & 0.4854 \\
\hline MPR & 0.558755 & 5.215878 & 0.107126 & 0.9157 \\
\hline INTR & 1.697928 & 3.954184 & 0.429400 & 0.6720 \\
\hline G_M2 & 1.438339 & 1.280460 & 1.123299 & 0.2740 \\
\hline EXR & 0.901562 & 0.335393 & 2.688077 & 0.0138 \\
\hline C & 235.5590 & 105.8539 & 2.225322 & 0.0371 \\
\hline R-squared & 0.434751 & & & \\
\hline Adjusted R-squared & 0.300168 & & & \\
\hline F-statistic & 3.230356 & & & \\
\hline Prob(F-statistic) & 0.025598 & & &
\end{tabular}

Source: Extracts from E-view

\subsection{Interpretation of Results}

From the regression results, the coefficient of determination $\left(\mathrm{R}^{2}\right)$ shows that $43.4 \%$ and 30 . $0 \%$ variance in the return on equity of insurance companies can be traced to the independent variables in the model. The Durbin Watson statistics of 2.08 indicate the presence of negative serial autocorrelation between the variables. The F-statistics of 3.2303356 at the probability of 0.0025598 signify goodness of fit of the model and conclude that there is significant relationship between the independent variables and the dependent variable.

The regression intercept shows the positive effect of the dependent variable at constant. The independent variables are positively related to the dependent variable except Treasury bill rate. The positive coefficient of 1.69 as parameter for interest rate, 0.558 as parameter for monetary policy rate, 3.559, 1.438 as Growth of money supply and 0.901 for exchange rate indicates that an increase of $1 \%$ will lead to increase return on equity of the quoted insurance firms $1.6 \%, 0.5 \%, 0.9 \%, 3.5 \%$, while the negative coefficient of 3.128 will reduce return on investment by $3.1 \%$.

Table 2: Unit Root Test Summary Results at Level

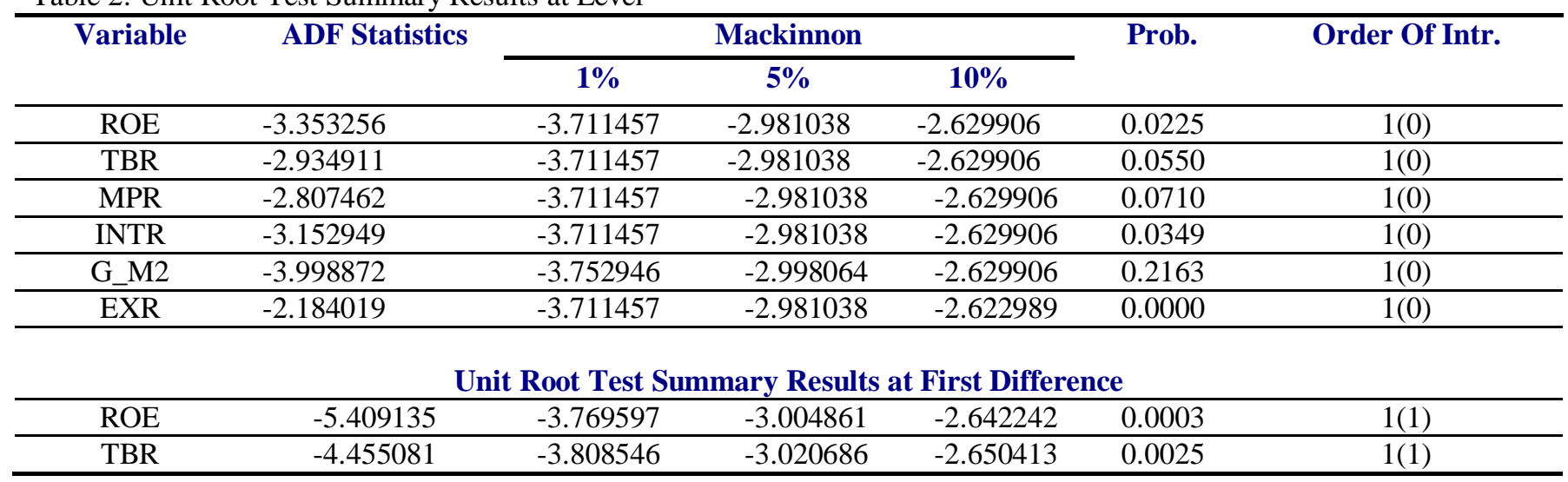




\begin{tabular}{ccccccc}
\hline MPR & -6.952318 & -3.724070 & -2.986225 & -2.632604 & 0.0000 & $1(1)$ \\
\hline INTR & -8.903711 & -3.752946 & -2.998064 & -2.638752 & 0.0000 & $1(1)$ \\
\hline G_M2 & -4.464667 & -3.788030 & -3.012363 & -2.646119 & 0.0023 & $1(1)$ \\
\hline EXR & -4.422308 & -3.724070 & -2.986225 & -2.632604 & 0.0019 & $1(1)$ \\
\hline
\end{tabular}

Source: Extracts from E-view

The stationarity of the variables were examined using the Augmented Dickey Fuller tests. The results of the stationarity test of the variables are presented in Table II. The results reveal the order of integration and the significance level of the variables of the model. After the application of the ADF test on the level and first difference series, the computed variables of the ADF statistics are more negative than the MacKinnon critical values; we therefore reject the null hypothesis that the time series data variables are non-stationary (have a unit root). The time series exhibit difference stationarity (i.e. stationary at first difference).

Table 3: Johansen Co-Integration Test Results: Maximum Eigen

\begin{tabular}{|c|c|c|c|c|c|}
\hline $\begin{array}{l}\text { Hypothesized } \\
\text { No. of CE(s) }\end{array}$ & Eigen value & Trace Statistics & $\begin{array}{c}0.05 \\
\text { Critical Value }\end{array}$ & Prob.*** & Decision \\
\hline None $*$ & 0.842539 & 127.8286 & 95.75366 & 0.0001 & Reject $\mathrm{H}_{0}$ \\
\hline At most $1 *$ & 0.752612 & 81.61417 & 69.81889 & 0.0043 & Reject $\mathrm{H}_{0}$ \\
\hline At $m+o s t 2$ & 0.551278 & 46.69427 & 47.85613 & 0.0640 & Reject $\mathrm{H}_{0}$ \\
\hline At most 3 & 0.437992 & 26.66048 & 29.79707 & 0.1102 & Accept $\mathrm{H}_{0}$ \\
\hline At most 4 & 0.274238 & 12.25448 & 15.49471 & 0.1451 & Accept $\mathrm{H}_{0}$ \\
\hline At most $5 *$ & 0.156036 & 4.241139 & 3.841466 & 0.0394 & Accept $\mathrm{H}_{0}$ \\
\hline \multicolumn{6}{|c|}{ Trace Statistics } \\
\hline None $*$ & 0.842539 & 46.21446 & 40.07757 & 0.0090 & Reject $\mathrm{H}_{0}$ \\
\hline At most $1 *$ & 0.752612 & 34.91990 & 33.87687 & 0.0374 & reject $\mathrm{H}_{0}$ \\
\hline At most 2 & 0.551278 & 20.03379 & 27.58434 & 0.3388 & Accept $\mathrm{H}_{0}$ \\
\hline At most 3 & 0.437992 & 14.40600 & 21.13162 & 0.3326 & Accept $\mathrm{H}_{0}$ \\
\hline At most 4 & 0.274238 & 8.013342 & 14.26460 & 0.3774 & Accept $\mathrm{H}_{0}$ \\
\hline At most $5 *$ & 0.156036 & 4.241139 & 3.841466 & 0.0394 & Reject $\mathrm{H}_{0}$ \\
\hline
\end{tabular}

Source: Extracts from E-view

Having established the presence of unit root in most of our variables, we conducted multivariate cointegration tests using Johansen Maximum Likelihood tests to determine whether a long run relationship exist between the variables of the model. The results of the cointegration test presented in the table III above. The results of the Johansen's co-integration test reflect the two statistics test namely, the trace statistic and the maximum eigen-value proposed by Johansen and Juselius (1990). From the Tables, the trace statistic is small when the values of the characteristic roots are closer to zero (and its value will be large in relation to the values of the characteristic roots which are further from zero).

The other test, the maximum eigen-value is an alternative test statistic which tests the null hypothesis that the number of $\mathrm{r}$ co-integrated vectors is $\mathrm{r}$ against the alternative of $(\mathrm{r}+1)$ co- integrated vectors. (i.e. the null hypothesis $r=0$ is tested against the alternative that $r=1 ; r=1$ against the alternative $r=2$ ). If the estimated value of the characteristic root is found to be close to zero, then the maximum eigen-value will be small.

The co-integration results suggest the existence of two co-integrating vectors as the trace statistics rejects the null hypothesis of no co-integrating vector at 5\% significant level and accept the alternate hypothesis two co-integrating vectors. Similarly, the maximum eigen-value rejects the null hypothesis of $r=0$ co-integrating vector at 5\% significant level and accepts the alternate hypothesis of two co-integrating vectors. Therefore, since both test statistics suggest the presence of two co-integrating vector, we can conclude that the variables are co-integrated and follow long-run equilibrium relationship.

Table 4: Normalized Conintegrating Equation

\begin{tabular}{|c|c|c|c|c|c|}
\hline ROE & TBR & MPR & INTR & G_M2 & EXR \\
\hline 1.000000 & -16.68808 & 3.265243 & 9.267604 & 0.185339 & -1.814423 \\
\hline
\end{tabular}


Test for normalized cointegration is necessary to ascertain the direction of long run relationship between the dependent variable and independent variables. From the table above, treasury bills and exchange rate have negative long run while monetary policy, interest rate and growth of money supply have positive long run effect on return on equity of the quoted insurance firms.

Table 5: Error Correction Estimate

\begin{tabular}{|c|c|c|c|c|c|}
\hline Error Correction: & D(ROE) & D(TBR) & D(MPR) & D(INTR) & D(G_M2) \\
\hline \multirow[t]{3}{*}{ CointEq1 } & -0.291610 & -0.015426 & 0.009619 & 0.026969 & 0.045262 \\
\hline & $(0.24888)$ & $(0.00982)$ & $(0.00513)$ & $(0.00643)$ & $(0.03422)$ \\
\hline & {$[-1.17167]$} & {$[-1.57109]$} & {$[1.87602]$} & [4.19338] & {$[1.32251]$} \\
\hline \multirow[t]{3}{*}{ CointEq2 } & -7.608238 & -1.290766 & 0.921757 & 1.211761 & 4.573301 \\
\hline & $(16.4824)$ & $(0.65025)$ & $(0.33957)$ & $(0.42591)$ & $(2.26649)$ \\
\hline & {$[-0.46160]$} & {$[-1.98502]$} & [2.71448] & [2.84510] & [2.01779] \\
\hline \multirow[t]{3}{*}{$\mathrm{C}$} & 14.43325 & -0.518821 & 0.105338 & 1.028680 & 1.885706 \\
\hline & $(25.6970)$ & $(1.01378)$ & $(0.52941)$ & $(0.66402)$ & $(3.53359)$ \\
\hline & {$[0.56167]$} & {$[-0.51177]$} & {$[0.19897]$} & [ 1.54917$]$ & {$[0.53365]$} \\
\hline R-squared & 0.556701 & 0.551684 & 0.850064 & 0.863455 & 0.627888 \\
\hline Adj. R-squared & 0.073103 & 0.062613 & 0.686497 & 0.714496 & 0.221947 \\
\hline Sum sq. resids & 152532.0 & 237.4014 & 64.74072 & 101.8491 & 2884.225 \\
\hline S.E. equation & 117.7563 & 4.645638 & 2.426009 & 3.042862 & 16.19266 \\
\hline F-statistic & 1.151164 & 1.128023 & 5.197053 & 5.796615 & 1.546748 \\
\hline Log likelihood & -139.1394 & -61.55491 & -45.96256 & -51.39978 & -91.52202 \\
\hline Akaike AIC & 12.67829 & 6.212909 & 4.913547 & 5.366649 & 8.710168 \\
\hline Schwarz SC & 13.31640 & 6.851022 & 5.551659 & 6.004761 & 9.348281 \\
\hline Mean dependent & 7.036250 & -0.173333 & -0.031250 & 0.437917 & -0.312083 \\
\hline S.D. dependent & 122.3118 & 4.798282 & 4.332833 & 5.694772 & 18.35751 \\
\hline \multicolumn{2}{|c|}{ Determinant resid covariance (dof adj.) } & $2.69 \mathrm{E}+08$ & & & \\
\hline \multicolumn{2}{|c|}{ Determinant resid covariance } & 5443935. & & & \\
\hline \multicolumn{2}{|c|}{ Log likelihood } & -356.3928 & & & \\
\hline \multicolumn{2}{|c|}{ Akaike information criterion } & 35.94940 & & & \\
\hline \multicolumn{2}{|c|}{ Schwarz criterion } & 39.63082 & & & \\
\hline
\end{tabular}

Source: Extracts from E-view

Results from error correction estimates proved that return on equity and treasury bills have negative coefficient while other variables in the model have positive coefficient in equation I this also confirm the results in equation II. The $\mathrm{R}^{2}$ and adjusted $\mathrm{R}^{2}$ shows the explained variation of the variables.

Table 6: Parsimonious Error Correction Results

\begin{tabular}{crccc}
\hline Variable & Coefficient & Std. Error & t-Statistic & Prob. \\
\hline C & 22.20226 & 23.58401 & 0.941412 & 0.3637 \\
\hline D(ROE(-1)) & 0.390055 & 0.475306 & 0.820639 & 0.4266 \\
\hline D(ROE(-2)) & -0.070217 & 0.361520 & -0.194228 & 0.8490 \\
\hline D(ROE(-3)) & -0.133370 & 0.230699 & -0.578110 & 0.5731 \\
\hline D(TBR(-1)) & 0.211941 & 4.788389 & 0.044262 & 0.9654 \\
\hline D(MPR(-2)) & -2.197283 & 5.266743 & -0.417200 & 0.6833 \\
\hline D(INTR(-1)) & -0.629065 & 4.381392 & -0.143576 & 0.8880 \\
\hline D(G_M2) & 2.897508 & 1.350514 & 2.145486 & 0.0514 \\
\hline
\end{tabular}




\begin{tabular}{|c|c|c|c|c|}
\hline $\mathrm{D}(\mathrm{EXR}(-1))$ & -1.616601 & 1.341164 & -1.205371 & 0.2495 \\
\hline $\operatorname{ECM}(-1)$ & -1.682663 & 0.617255 & -2.726040 & 0.0173 \\
\hline R-squared & 0.679901 & Mean dependent var & & 6.596522 \\
\hline Adjusted R-squared & 0.458293 & S.D. dependent var & & 125.0413 \\
\hline S.E. of regression & 92.03131 & Akaike info criterion & & 12.18116 \\
\hline Sum squared resid & 110106.9 & Schwarz criterion & & 12.67485 \\
\hline Log likelihood & -130.0833 & Hannan-Quinn criter. & & 12.30532 \\
\hline F-statistic & 3.068043 & Durbin-Watson stat & & 2.270015 \\
\hline Prob(F-statistic) & 0.032935 & & & \\
\hline
\end{tabular}

Source: Extracts from E-view

Information from the unit root tests, and the estimated co-integrating relationship were used to specify the short-run Error Correction dynamic Model. The test was conducted to reconcile the short-run and long run dynamism. The result obtained for the model is explained in Table $\mathrm{V}$ above. The coefficient of the error correction model for the estimated ROE equations is statistically significant and negative. Specifically, if the actual equilibrium value is too high, the error correction term will bring it down, while if it is too low, the error correction term will raise it. The value of the coefficient however implies that when ROE is out of its long run trend, 116\% of the error is corrected at each level to restore equilibrium but with a stronger and significant effect.

Statistically, the fit is good for ROE with $\mathrm{R}^{2}$ indicating $67.9 \%$ of the total variation as explained by the included variables. The remaining 32.1 percent of the total variation in ROE is unaccounted for by the regression line and is attributed to the factors included in the disturbance term $(\mu)$. The presence of unit root in the residual series usually drive Durbin-Watson test towards zero, but the value of this statistic (2.27), which is approximately 2, is within the acceptable limit for zero autocorrelation and it is considered interesting because it reinforces the acceptance of the null hypothesis of no serial correlation in the residual of the model.

Table 7: Pairwise Granger Causality Tests

\begin{tabular}{lccc}
\hline \multicolumn{1}{c}{ Null Hypothesis: } & Obs & F-Statistic & Prob. \\
\hline TBR does not Granger Cause ROE & 25 & 0.51402 & 0.6058 \\
\hline ROE does not Granger Cause TBR & & 4.30244 & 0.0279 \\
\hline MPR does not Granger Cause ROE & 25 & 0.45448 & 0.6412 \\
\hline ROE does not Granger Cause MPR & & 2.54165 & 0.1039 \\
\hline INTR does not Granger Cause ROE & 25 & 0.56170 & 0.5790 \\
\hline ROE does not Granger Cause INTR & & 0.18347 & 0.8338 \\
\hline G_M2 does not Granger Cause ROE & 25 & 0.28828 & 0.7526 \\
\hline ROE does not Granger Cause G_M2 & & 0.84385 & 0.4448 \\
\hline EXR does not Granger Cause ROE & 25 & 2.32850 & 0.1233 \\
\hline ROE does not Granger Cause EXR & & 0.66066 & 0.5274 \\
\hline
\end{tabular}

Source: Extracts from E-view

The results above show causality between private return on equity and monetary policy rate as well as their independent variables as used in this study. The null hypothesis in case of return on equity and monetary policy rate is not accepted. As stated in the methodology, null hypothesis is rejected if Fcal $>\mathrm{Ftab}$; accept otherwise, at 5\% level of significance. From result presented we say likewise, all other variables exhibit no causal relationship, therefore we accept the null hypothesis.

4.2 Test of Hypotheses

Treasury bill rate and return on equity: T-cal $\quad-0.710<2.080$ T-critical, Probability value $0.4854>0.05$, accept null hypothesis

Monetary policy rate and return on equity: T-cal $\quad 0.107<2.080$ T-critical, Probability value $0.9157>0.05$, accept null hypothesis

Interest rate and return on equity: T-cal $\quad 0.429<2.080$ T-critical, Probability value $0.6720>0.05$, accept null hypothesis

Growth of money supply and return on equity: T-cal $1.123<2.080$ T-critical, Probability value $0.2740>0.05$, accept null hypothesis. 
Exchange rate and return on equity: T-cal $2.688>2.080$ T-critical, Probability value $0.0138>0.05$, accept alternate hypothesis.

4.3 Discussion of Findings

Apart from the monetary policy objectives of achieving economic grows, full employment, price stability and external balance, one of the objective of monetary policy is to ensure financial market stability. According to the IMF report 1990 on financial stability index, profitability is a measure of financial stability. A profitable company is able to withstand monetary and macro economic shocks in the operating environment and maximize shareholders wealth. Again apart from the internal factors that determines profitability of the insurance firms, the monetary policy have been found to significantly impact on the performance of the financial institutions, this is because the financial market is a transmission mechanisms of the monetary policy.

The findings of this study revealed that monetary policy examined in this study have positive relationship with the performance of the insurance companies in Nigeria. This finding confirms the objective of monetary policy in ensuring financial system stability. The findings confirm the findings of Okoye (2014) on the positive impact of the monetary policy in investment of insurance companies in Nigeria, the findings in contrary with the finding of Jiwan (2012) on the negative relation between monetary variable and the performance of commercial bank in Nigeria. The positive relationship of the monetary policy variables can be trace to the fact that insurance company does not transit much of the monetary policies compared to the commercial banks.

\section{Conclusion}

The objective of this study was to establish the relationship between monetary policy and performance of insurance companies in Nigeria. Time series data were source from Central Bank of Nigeria statistical bulletin. The study modeled return on capital employed as the function of interest rate, monetary policy rate, Treasury bill rate, growth of money supply and exchange rate. From the findings $43.4 \%$ and $30.0 \%$ variation on return on equity of the insurance firms can be traced to the monetary policy variable examined in the study. From the above the study concludes that there is significant relationship between monetary policy and the performance of insurance companies in Nigeria.

6. Recommendations

The management of the insurance companies should device measures of managing the negative effect of monetary policy instrument on the performance of the insurance companies and the monetary authorities should harmonize the profitability objectives of the insurance companies with that of monetary policy to avert the negative effect.

Interest policies should be revisited or fully deregulated to allow market forces of demand and supply to avert the negative effect on the performance of the insurance firms and there should be expansionary monetary policy that enhances the investment of the insurance companies for better performance.

The operating environment of the insurance companies should be overhauled to enhance effective management of the monetary environment and there should also be measures to effectively manage the References monetary policy shocks that occur in the process of administering monetary policy.

Abate Gashaw. (2012)., Factors affecting profitability of Insurance Companies in Ethiopia: Panel Evidence, MSc Thesis, AAU.

Adebiyi, M. A., (2006). Financial Sector Reforms and the Transmission Mechanism of Monetary Policy in Nigeria. A Vector Auto-regression Mechanism, China Finance Research Network (CFRN). 1(2), 178-190.

Adefeso, H.A. \& Mobolaji, C., (2010). The fiscal-monetary policy and economic growth in Nigeria: Further empirical evidence. Pakistan Journal of Social Sciences, 7(2): 137-142.

Ajayi, S.I., (2005). An economic case study of the relative importance of monetary and fiscal policy in Nigeria. Bangladesh Economic Review, 2(2), 559-576.

Bernanke, B., J. Boivin. J., \& Eliasz V. W.,(2005). Measuring the effects of monetary policy: A factor-augmented vector autoregressive (favar) approach. The Quarterly Journal of Economics, 120(1), 287-422.

Berument, H., \& Dincer, N., (2008). Measuring the effects of monetary policy for turkey. Journal of Economics Cooperation, 29(1), 83-110.

Chukwulozie, O.E., (2006). Life insurance as a source of long time savings in Nigeria: Regulator's Perspective. CBN publication. 30(1), 20-31.

Daniel, M., \& Tilahun, A. (2013). Firm specific factors that determines Insurance companies performance in Ethiopia. European Scientific Journal, 9 (1), 134-153

Dube, M. M., and Saka (2017). An Analysis of Factors Affecting the Performance of Insurance Companies in Zimbabwe. Journal of Finance and Investment Analysis, 6(1), 45-69. 
Folawewo, A. O., and Osinubi, T. S., (2009). Monetary policy and macroeconomic instability in Nigeria : A rational expectation approach. Journal of Social Sciences, 12(2), 93-100.

Frimpong, N.W., \& Omar, O.E., (2007). Life insurance in Nigeria: An application of the theory of reasoned action to consumers' attitudes and purchase intension. The Service Industrial Journal. 27(7), 936-976.

Ganev, G., M. Krisztina, R. Krzysztof \& Prsemyslaw,W., (2002). Transmission mechanism of monetary policy in central and eastern Europe. Centre for Social and Economic Research (CASE)(Report No. 52).

Gonga, M. A., \& Sasaka, P. S. (2017). Determinants of financial performance of insurance firms: a survey of selected insurance firms in Nairobi county. The Strategic Journal of Business \& Change Management. $4(4), 123-143$.

Hadush, G. (2015). Determinants of Profitability of Insurance Companies in Ethiopia: AnEmpirical study, Master's Thesis, AAU.

Hailu, Z., (2007). Insurance in Ethiopia, Historical development present status, and future challenges. Master Printing press, Addis Ababa.

Hanna, M. (2015). Determinants of insurance companies' profitability in Ethiopia, Master's Thesis AAU.

Hawariyuni, W., (2006). The determinants of demand of Syarikat Takaful Malaysia Berhad (STMB): autoregressive distributive lag (ARDL) Approach of Co integration.

Hifza, M. (2011). Determinants of insurance companies' profitability: an Analysis of Insurance sector of Pakistan. Academic Research International, 1(3), 178-189.

Hwang, T., \& Gao, S., (2003). The determinants of the demand for life insurance in an emerging economy - the case of China. Managerial Finance, $29(5 / 6), .82-96$.

Kahn, M., K. Shmuel \& Oded,S., (2002). Real and nominal effects of central bank monetary policy. Journal of Monetary Economics (49), 1493-1519.

Kozak, S. (2015). Determinants of Profitability of Non-Life Insurance.Companies in Poland during Integration with the European Financial System.

Lee, C.H., Wong, A.K., \& Chen, R., (2001). Age, period, and cohort effects on life insurance purchases in the U.S. The Journal of Risk and insurance. 68(2), 303-327.

Malik, H., (2011). Determinants of insurance companies' profitability: An analysis of insurance sector of Pakistan. Academic Research International. 1(3), 65-82.

Mistre, S. (2015). The Determinants of Profitability on Insurance sector: evidence from Insurance Companies in Ethiopia, MSc. thesis AAU.

Molho, L. E., (2007). Interest Rate, Saving and Investment in Developing Countries. IMF Staff Paper, 83(1), 90116.

Moullec, L.E., Kucinskience, M., \& Ulbinaite, A., (2013). Determinants of insurance purchase decision making in Lithuania. Inzinerine Ekonomika-Engineering Economics. 24(2), 144-159.

Niño Datu(2016). How do insurer specific indicators and macroeconomic factors affect the profitability of insurance business? A panel data analysis on the Philippine Non-life Insurance market

Oke, O.B., Ideji, O.J., \& Joseph, I.A., (2010). The determinants of life insurance consumption in Nigeria: A cointegration approach. International Journal of Academic Research. 2(4), 109-123.

Öner Kaya (2013). Capital Adequacy in the Insurance Business and Assessment of Turkish Insurance Sector within the Scope of Solvency II. Ph.D. Thesis, Gazi University, Ankara,

Onoh, J. K. (2002). Dynamics of Money Banking and Finance in Nigeria. An emerging market. Astra Meridian

Publishers, Aba, Nigeria.

Onyeiwu, C., (2012). Monetary policy and economic growth of Nigeria. Journal of Economics and Sustainable Development, 3(7), $62-70$.

Ornella M. L.Anderloni (2014). Non-life Insurance Economic performance an empirical investigation. Journal of economics and management, $18(2), 16-27$.

Pervan, M., \& Pavić, K.T., (2010). Determinants of Insurance Companies' Profitability in Croatia. The Business Review Cambridge, 16(1), 231-238.

Rafiq, M.S. \& Mallick,S.K., (2008). The effect of monetary policy on output in emu: A sign restriction approach. Journal of Macroeconomics 30: 1756-1791.

Sojic, M., \& Djurdjevic, L., (2008). .Monetary Policy Objectives and Instruments Used by the Privileged National Bank of the Kingdom of Serbia (1884-1914).

Starr, M., (2005). Does money matter in the cis? Effects of monetary policy on output and prices. Journal of Comparative Economics 33: 441-461.

Suheli Reshid (2015). Determinants of Insurance Companies in Ethiopia, MSc Thesis, AAU. 
Tavlas, G., H., \& Stockman, A., (2008).The Classification and Performance of Alternative Exchange-Rate Systems. International journal of money and banking 5(7) 130-152.

Ward, D. \& Zurbruegg,R., (2002). Law, Politics and Life Insurance Consumption in Asia. Geneva Papers on Risk and Insurance. 27; 395-412.

Yana, S. (2010), Factors that determined firm performance of New Zealand listed companies, MBUS thesis

Yugi, L, (2007). Determinates of Banks profitability and its implication on risk management practices panel evidence from the UK, the University of Nottingham.

Yuvaraj and Abate G. (2013). Performance of Insurance Companies in Ethiopia, International Journal of Marketing. Financial Services and Management research ,3(1),12-31.

\section{Copyrights}

Copyright for this article is retained by the author(s), with first publication rights granted to the journal.

This is an open-access article distributed under the terms and conditions of the Creative Commons Attribution license (http://creativecommons.org/licenses/by/4.0/). 